\title{
Saprolegnia species affecting the salmonid aquaculture in Chile and their associations with fish developmental stage
}

\author{
Jose Vladimir Sandoval-Sierra a, Fadua Latif-Eugenin ${ }^{\text {b }}$, María P. Martín a , \\ Luis Zaror $^{\mathrm{b}, 1}$, Javier Diéguez-Uribeondo ${ }^{\mathrm{a}, *}$ \\ a Departamento de Micología, Real Jardín Botánico CSIC, Plaza Murillo 2, 28014 Madrid, Spain \\ b Instituto de Microbiología Clínica, Facultad de Medicina, Universidad Austral de Chile, Valdivia, Chile
}

\section{A R T I C L E I N F O}

\section{Article history:}

Received 15 July 2014

Received in revised form 28 August 2014

Accepted 4 September 2014

Available online 16 September 2014

\section{Keywords:}

Oomycetes

Pathogen

Salmon

ITS nrDNA

MOTUs

\begin{abstract}
A B S T R A C T
The rapid increase in the aquaculture production of salmonids has been followed by a rise in several diseases. In particular, saprolegniosis can account for at least $10 \%$ of the annual economic loss in salmonids. In this study, we investigated the main Saprolegnia species involved in saprolegniosis of salmonids in Chile, and their association with specific developmental stages of the host fish. For this purpose, we studied 244 isolates of Saprolegniaaffected Atlantic salmon (Salmo salar), rainbow trout (Oncorhynchus mykiss), and king salmon (Oncorhynchus tshawytscha) from the salmon farming regions, using a recently developed identification strategy based on molecular taxonomical operational units. We found that the Saprolegnia species associated with diseased salmon were Saprolegnia australis, Saprolegnia delica, Saprolegnia diclina, Saprolegnia ferax, Saprolegnia parasitica and two new Saprolegnia species observed during this study. In order to determine whether there were any specific species associations with different stages in the fish life cycle, we applied mosaic plots and correspondence analyses for categorical data. These analyses showed a strong association of $S$. parasitica with samples from the adult stage of the fish ( $\chi^{2}=196.29, p<0.0001$ ), while the species S. australis, S. diclina and Saprolegnia sp. 2 were strongly associated with embryonic stages (eggs or alevins) $\left(\chi^{2}=196.29, p<0.0001\right)$. This work represents the first detailed molecular characterization of Saprolegnia species involved in saprolegniosis in Chile, and the first study showing specific association of different Saprolegnia species with different stages in the salmonid life cycle.
\end{abstract}

(c) 2014 Elsevier B.V. All rights reserved.

\section{Introduction}

The aquaculture production of salmonids in Chile has increased dramatically during the last decade (Ibieta et al., 2011) and has become the second largest of the world, only preceded by Norway (Bravo and Midtlyng, 2007; Ibieta et al., 2011). The majority of this production corresponds to Atlantic salmon (Salmo salar) (40.7\%), rainbow trout (Oncorhynchus mykiss) (34.6\%), and coho salmon (Oncorhynchus kisutch) (24.6\%) (FAO, 2011). This rapid increase has also been followed by the rise of several diseases, e.g., infectious anemia disease (ISA) (Asche et al., 2009; Bravo and Midtlyng, 2007; Cárdenas et al., 2014; Ibieta et al., 2011), which nearly caused the collapse of the Chilean aquaculture in 2010 (Ibieta et al., 2011).

Diseases are one of the most detrimental threats in aquaculture (Moran and Fofana, 2007; Murray and Peeler, 2005). In farmed salmonids, the majority of pathologies are caused by bacteria, fungi, sea lice,

\footnotetext{
* Corresponding author. Tel.: + 349142030 17; fax: + 34914200157.

E-mail address: dieguez@rjb.csic.es (J. Diéguez-Uribeondo).

1 Current address: Instituto de Microbiología, Escuela de Tecnología Médica, Universidad Mayor de Temuco, Chile.
}

water molds (Oomycetes) and viruses (Bostock et al., 2010; Cárdenas et al., 2014; Igboeli et al., 2014; Meyer, 1991). In particular, water molds such as Saprolegnia, represent one of the most prominent sources of disease and their impact is comparable to bacterial and see lice infections (Costello, 2006; Meyer, 1991; Noga, 1993). Globally, Saprolegnia is thought to be responsible for at least $10 \%$ of the annual economic loss in salmonids (Hussein and Hatai, 2002; Phillips et al., 2008; Robertson et al., 2009; van den Berg et al., 2013). In some cases, these infections may represent up to $50 \%$ of the total annual production loss (Bly et al., 1992; Bruno et al., 2011; Hatai and Hoshiai, 1992a; van West, 2006). The most common sign of saprolegniosis in adult fish is a superficial "cotton like" growth with a white growth of mycelia on the fish skin, especially around the head, dorsal and caudal fins, gills, and in the muscular layer and internal organs (Fregeneda-Grandes et al., 2001; Hussein et al., 2001). In the embryonic stage, the typical symptom is the outgrowth of "cotton like" mycelium (Fernández-Benéitez et al., 2008; Rezinciuc et al., 2014). Currently, the lack of an effective chemical control has resulted in a rapid increase in the number of reported cases of saprolegniosis in fish farms (Cao et al., 2012; Fregeneda-Grandes et al., 2007; Ghiasi et al., 2010; Rezinciuc et al., 2014; Thoen et al., 2011; Vega-Ramírez et al., 2013). In the past the consequence of this 
disease was generally discounted because it was easily controlled with malachite green (Bailey, 1984; Robertson et al., 2009; van West, 2006). However, the use of this chemical was banned due to its carcinogenic and toxicological effects (Srivastava et al., 2004; van West, 2006). Alternative products had been tested for anti-Saprolegnia activity (Arndt et al., 2001; Gaikowski et al., 1998; Gieseker et al., 2006; Rach et al., 2005), but none of these compounds seem to provide an efficient control of Saprolegnia as the banned malachite green (van West, 2006).

Saprolegnia infections seem to be mainly caused by the species: Saprolegnia parasitica, Saprolegnia diclina, and Saprolegnia australis (Diéguez-Uribeondo et al., 1996; Rezinciuc et al., 2014; van den Berg et al., 2013; van West, 2006; Willoughby, 1978). While S. parasitica is often reported in infections of adult fish (Diéguez-Uribeondo et al., 2007; Fregeneda-Grandes et al., 2007; Songe et al., 2013; Tiffney, 1939; Willoughby, 1978), other species such as S. diclina are more often found in eggs (Diéguez-Uribeondo et al., 2007; Fregeneda-Grandes et al., 2007; van den Berg et al., 2013). However, to date there are no studies showing clear associations between Saprolegnia species and the fish developmental stage.
In Chile, the first recorded case of disease caused by oomycetes was attributed to S. parasitica (Zaror et al., 2004). This pathogen was presumably isolated from embryonic and adult specimens of Atlantic salmon, coho salmon, and rainbow trout that originated from freshwater farms (Zaror et al., 2004). However, not all Saprolegnia pathogens may have been recognized as only morphological characters were used in identifications. An accurate identification of Saprolegnia species usually requires the use of molecular approaches since morphological characters are ambiguous, and often absent (Diéguez-Uribeondo et al., 2007; Willoughby, 1978). The recent development of a molecular taxonomy of Saprolegnia has allowed us to accurately identify species of this genus without the need of difficult and often ambivalent studies of morphological traits (SandovalSierra et al., 2014). Since studies on Saprolegnia species related to saprolegniosis in Chilean freshwater aquaculture have been limited in number and scope, the aim of this study was to uncover the primary species associated with this disease in the salmonids of Chile, and to define whether there is any association of these pathogenic species to fish developmental stages.

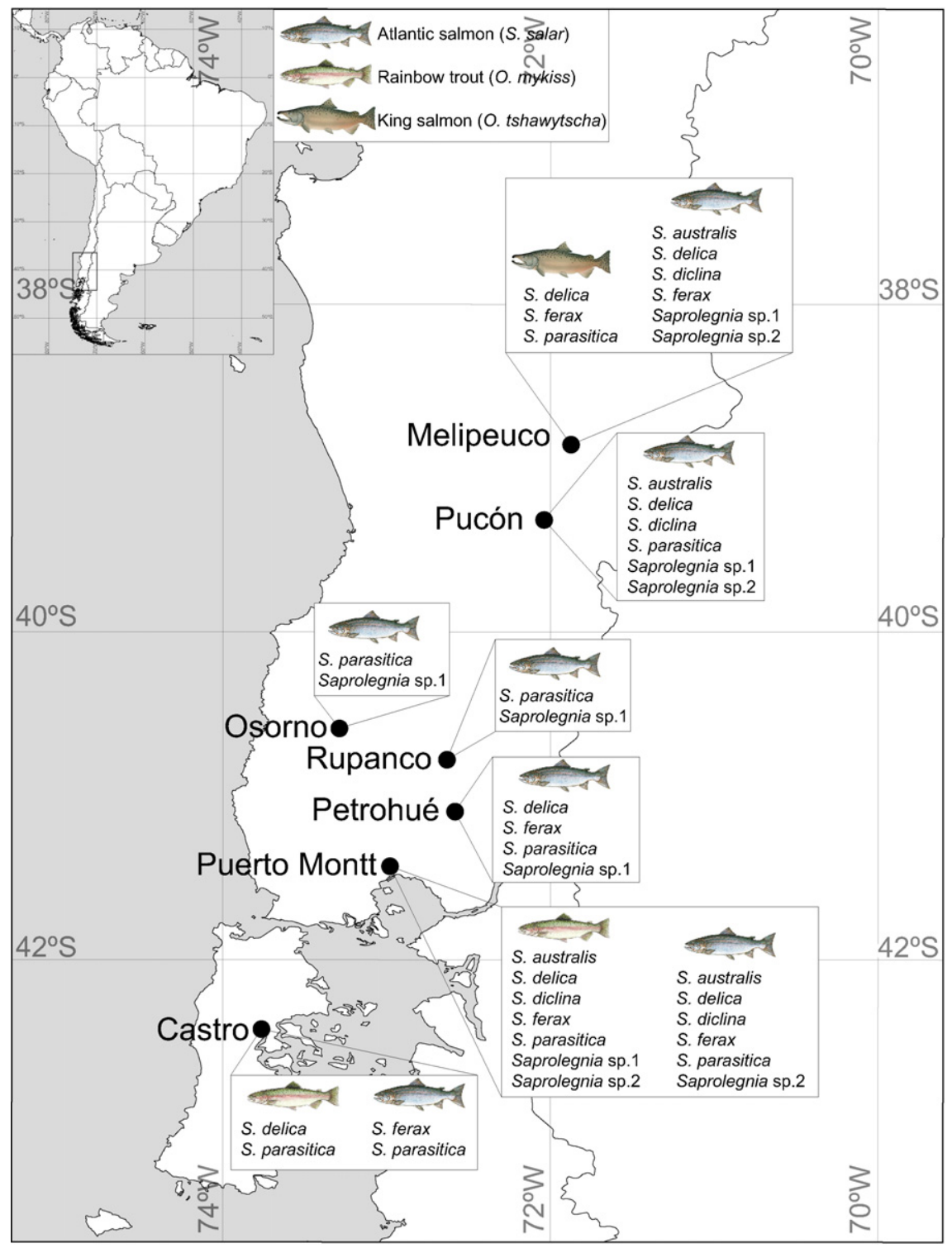

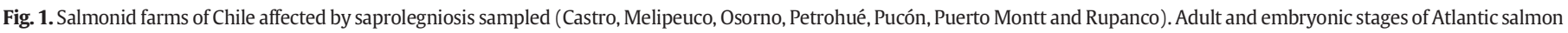
(Salmo salar), rainbow trout (Oncorhynchus mykiss), and king salmon (Oncorhynchus tshawytscha) were investigated. 


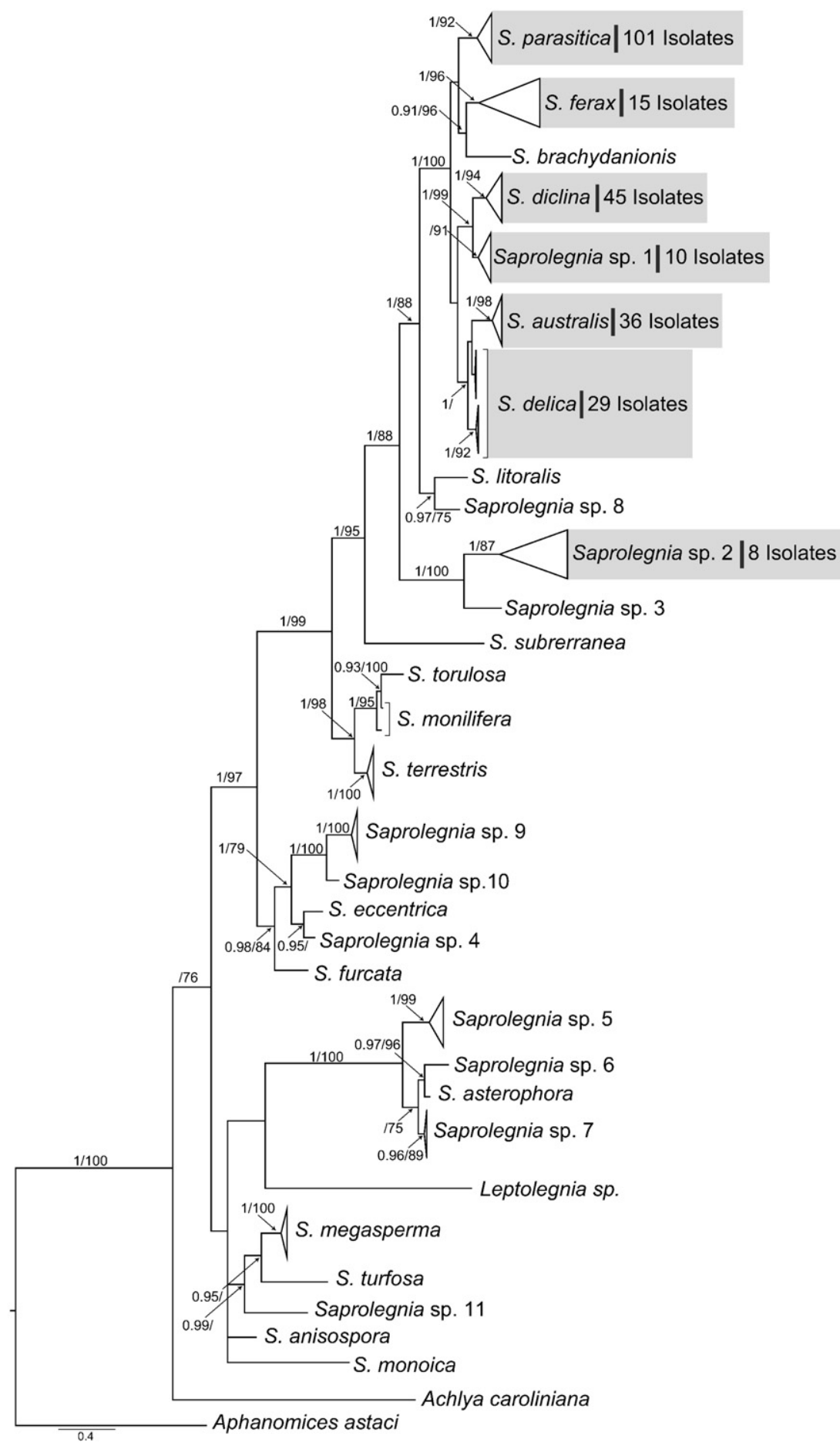

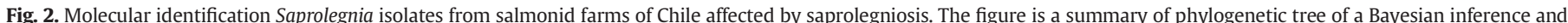

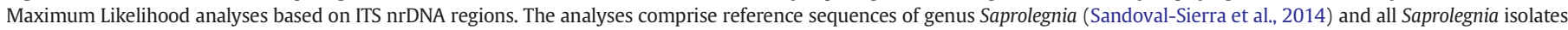

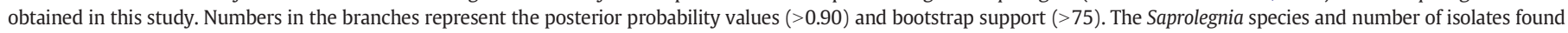
in this study are shown in light gray.

\section{Materials and methods}

\subsection{Isolates and morphological identification}

Samples were collected from seven fish farms located at Castro, Melipeuco, Osorno, Petrohué, Pucón, Puerto Montt and Rupanco during the period from 2007 to 2013 (Fig. 1). These farms were exclusively devoted to the aquaculture of salmonids, which comprised of the following species: Atlantic salmon, rainbow trout, and king salmon (Oncorhynchus tshawytscha). In all farms, samples from specimens showing symptoms of Saprolegnia infections at adult or embryonic (eggs and alevins) stages were collected. The samples from the adult stage originated from fish farms of Castro (Atlantic salmon and rainbow trout), Melipeuco (King salmon, and rainbow trout), Osorno (Atlantic salmon), Petrohué (Atlantic salmon), Pucón (Atlantic salmon and rainbow trout), Puerto Montt (Atlantic salmon and rainbow trout) and 
Table 1

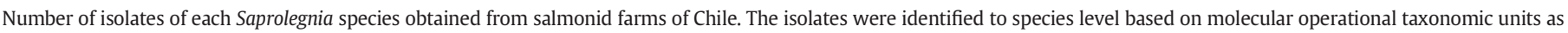
described by Sandoval-Sierra et al. (2014).

\begin{tabular}{|c|c|c|c|c|c|c|c|c|c|c|c|c|c|}
\hline \multirow[t]{3}{*}{ Specie } & \multicolumn{9}{|c|}{ Adult stage } & \multicolumn{4}{|c|}{ Embryonic stage } \\
\hline & \multicolumn{2}{|l|}{ Castro } & \multirow{2}{*}{$\frac{\text { Melipeuco }}{\text { O. tshawytscha }}$} & \multirow{2}{*}{$\frac{\text { Osorno }}{\text { S. salar }}$} & \multirow{2}{*}{$\frac{\text { Petrohué }}{\text { S. salar }}$} & \multirow{2}{*}{$\frac{\text { Pucón }}{\text { S. salar }}$} & \multicolumn{2}{|c|}{ Puerto Montt } & \multirow{2}{*}{$\frac{\text { Rupanco }}{\text { S. salar }}$} & \multirow{2}{*}{$\frac{\text { Melipeuco }}{\text { S. salar }}$} & \multirow{2}{*}{$\frac{\text { Pucón }}{\text { S. salar }}$} & \multicolumn{2}{|c|}{ Puerto Montt } \\
\hline & O. mykiss & S. salar & & & & & O. mykiss & S. salar & & & & O. mykiss & S. salar \\
\hline S. australis & 0 & 0 & 0 & 0 & 0 & 0 & 0 & 0 & 0 & 8 & 11 & 6 & 11 \\
\hline S. delica & 2 & 0 & 1 & 0 & 2 & 1 & 0 & 2 & 0 & 4 & 10 & 3 & 4 \\
\hline S. diclina & 0 & 0 & 0 & 0 & 0 & 0 & 0 & 0 & 0 & 11 & 14 & 7 & 13 \\
\hline S. ferax & 0 & 3 & 2 & 0 & 2 & 0 & 0 & 0 & 0 & 2 & 0 & 1 & 5 \\
\hline S. parasitica & 9 & 20 & 12 & 6 & 16 & 15 & 7 & 10 & 6 & 0 & 0 & 0 & 0 \\
\hline Saprolegnia sp. 1 & 0 & 0 & 0 & 1 & 1 & 3 & 0 & 0 & 1 & 1 & 2 & 1 & 0 \\
\hline Saprolegnia sp. 2 & 0 & 0 & 0 & 0 & 0 & 0 & 0 & 0 & 0 & 2 & 2 & 2 & 2 \\
\hline
\end{tabular}

Rupanco (Atlantic salmon). Samples from embryonic stages were collected from Melipeuco (Atlantic salmon), Pucón (Atlantic salmon) and Puerto Montt (Atlantic salmon and Rainbow trout) farms.

The isolations from adult fish were carried out by collecting one sample from the following diseased tissues: gill plates, fins, or skin tissues. Isolations from embryonic stages were performed by collecting one sample of eggs or alevins showing a "cotton like" growth. All samples collected were washed in autoclaved distilled water supplemented with $100 \mathrm{mg} \mathrm{l}^{-1}$ penicillin C (Rezinciuc et al., 2014), and placed onto Petri dishes with peptone glucose agar (PGA) (Cerenius et al., 1987). All isolates were maintained on PGA in the culture collection of the Real Jardín Botánico, Madrid, Spain.

A preliminary identification of the isolates to the genus level was performed based on microscopic observations by using an Olympus CKX41SF inverted microscope (Olympus Optical, Tokyo, Japan). For this purpose, isolates were grown in drop cultures of peptone glucose liquid media (PG1), for $2 \mathrm{~d}$ at $20^{\circ} \mathrm{C}$ and allowed to sporulate as described by Diéguez-Uribeondo et al. (1994). The isolates were assigned to the genus level according to the discharge of zoospores (Coker, 1923).

\subsection{DNA extraction and PCR conditions}

DNA was extracted from mycelia grown in drop cultures of PG1 for 2-3 d at $20{ }^{\circ} \mathrm{C}$ as described in Diéguez-Uribeondo et al. (2007). DNA extractions were carried out using DNeasy Plant Mini Kit (QIAGEN, Valencia, California, USA). The internal transcribed spacer region (ITS) was amplified using universal primers for eukaryotes ITS5 and ITS4 (White et al., 1990) under the conditions illustrated in Sandoval-Sierra et al. (2014). Amplified products were sequenced using an automated sequencer (Applied Biosystems 3730xl DNA, Macrogen, Netherlands). For each isolate, the consensus sequences for ITS region were assembled and edited using the program Geneious v6.14 (Kearse et al., 2012).

\subsection{Molecular identification of species}

For molecular identification at the species level, the ITS nrDNA sequences obtained from all isolates were merged with 62 Saprolegnia reference sequences assigned by Sandoval-Sierra et al. (2014) using the software Geneious v6.1.4 (Kearse et al., 2012). Mafft v7.0 was used for the alignment (Katoh and Standley, 2013). The sequences were analyzed using Bayesian inference and Maximum Likelihood as described in Sandoval-Sierra et al. (2014), and the isolates were assigned to species based on reference sequences for molecular operational taxonomic units (MOTUs) designated by Sandoval-Sierra et al. (2014). For Bayesian inference analysis the nucleotide model evolution GTR was obtained by running the data sets in jModelTest 2 (Darriba et al., 2012). The Bayesian inference was performed using MrBayes v3.2.1 (Ronquist et al., 2012). The Maximum Likelihood analysis was carried out with RaxML (Stamatakis, 2006), using the graphical user interface raxmlGUI v7.4.2 (Silvestro and Michalak, 2012). Phylogram trees were visualized with Figtree (http://tree.bio.ed.ac.uk/software/ figtree/).

\subsection{Analysis of Saprolegnia species associations}

Associations of Saprolegnia species with salmonid species, farm, and the developmental stage of the fish specimens were studied by applying two types of analyses:

(i) Correspondence analysis, which graphically represents the row and column categories, and allows a comparison of their associations at a category level in a subspace of lowdimensionality, e.g., two-dimensions (Beh, 2004; Nenadić and Greenacre, 2007). This analysis produces a dimensional plot of the data variation, which helps with observing overlaps between categorical variables (Beh, 2004). The relationships among frequencies were displayed in a two-dimension plot. Dimensions 1 and 2 both indicated the percentage of association between the row and column categories (Greenacre, 2007).

(ii) Mosaic plots (Friendly, 1994), which generate an areaproportional visualization of (typically, observed) frequencies, composed of tiles (corresponding to the cells) created by recursive vertical and horizontal splits of a rectangle (Meyer et al., 2006). Unlike traditional test statistics, this analysis enables the visualization of contingency tables that cannot be obvious from a numerical output (Meyer et al., 2006). The associations observed were tested using Pearson's $\chi^{2}$-test. This $\chi^{2}$-test analysis is based on the maximum of the absolute values of the Pearson residuals generated by 10,000 permutations (Meyer et al., 2006), and allows visualization of residuals from a given statistical test (Friendly, 1994; Meyer et al., 2006). Pearson residuals are approximately standard normal, which implies that the highlighted cells are those with residuals individually significant at approximately $\alpha=0.05$ and $\alpha=0.0001$ levels, respectively (Meyer et al., 2006).

All analyses were performed in R version 3.02 ( $R$ Development Core Team, 2010). The correspondence analysis was carried out with the associated module "ca" v 0.53 (Nenadić and Greenacre, 2007) and the mosaic plots were performed with the associated module "vcd" v 1.3-1 (Meyer et al., 2006).

\section{Results}

\subsection{Strain isolation and molecular identification}

A total of 244 isolates were obtained from all salmon species samples (Table A.1, Fig. 1). Microscopic observations showed that all isolates have a saprolegnoid type of discharge characteristic to the genus Saprolegnia (Coker, 1923). For molecular identification to the species level, a number of 244 nrDNA ITS sequences from 651 to $677 \mathrm{bp}$ were generated from all isolates. These sequences were aligned with 62 reference sequences for Saprolegnia species according to the description by Sandoval-Sierra et al. (2014). Based on the obtained alignment, a matrix of 746 characters was 
a)

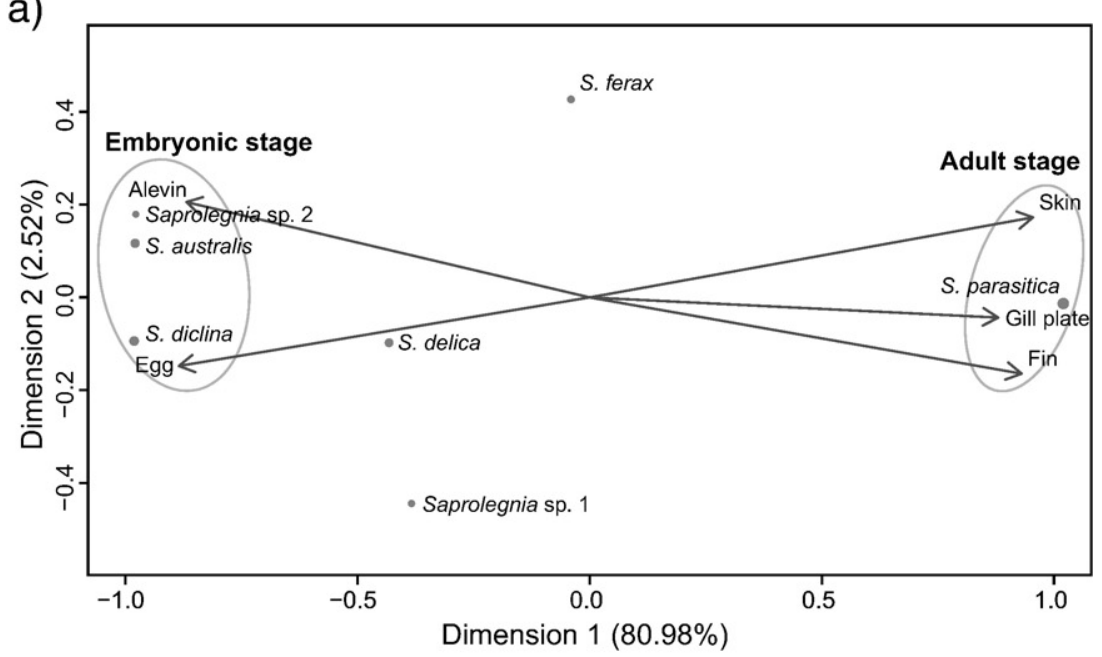

b)

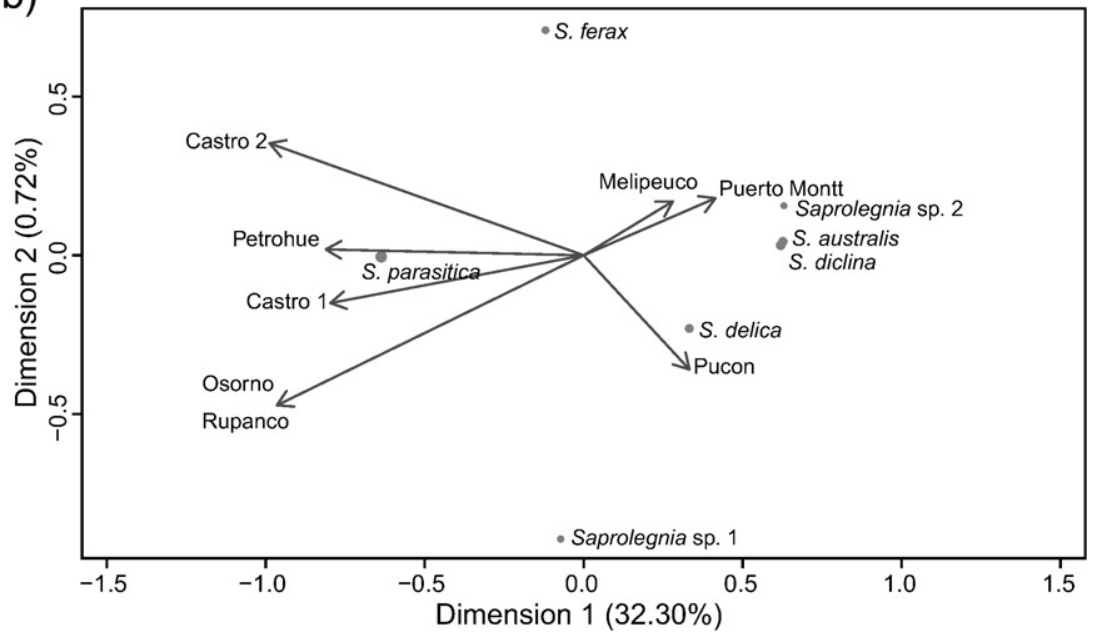

c)

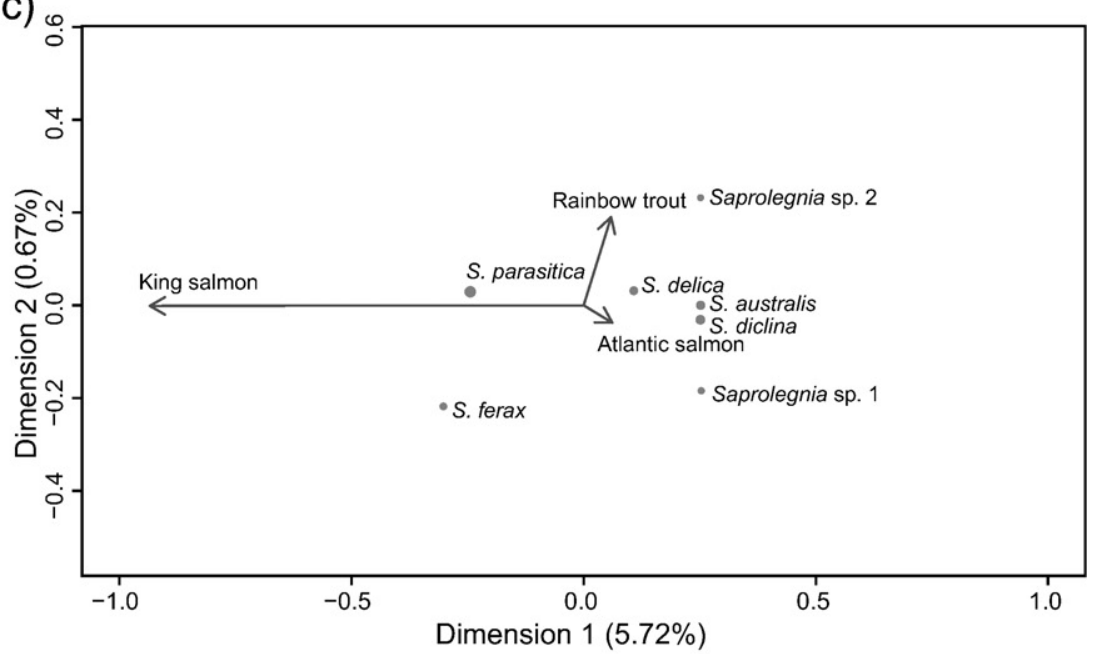

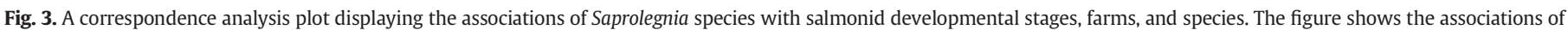

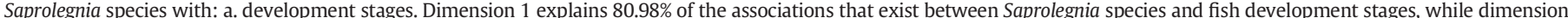

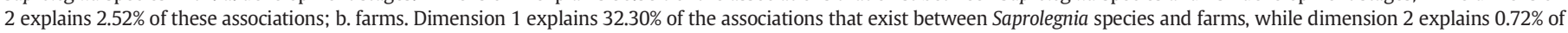

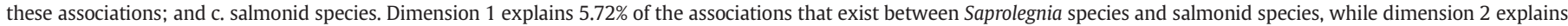
$0.67 \%$ of these associations.

generated. The phylogenetic and the molecular taxonomic analyses showed that these sequences corresponded to the following MOTUs (Fig. 2): S. parasitica (101 isolates), S. diclina (45 isolates), S. australis (36 isolates), Saprolegnia delica (29 isolates), Saprolegnia ferax (15 isolates), Saprolegnia sp. 1 (10 isolates) and Saprolegnia sp. 2 (8 isolates) (Table A.1).

From the tissue samples of the diseased adult stage, a total of 122 isolates of Saprolegnia were obtained from all farms (89 isolates for 
a)
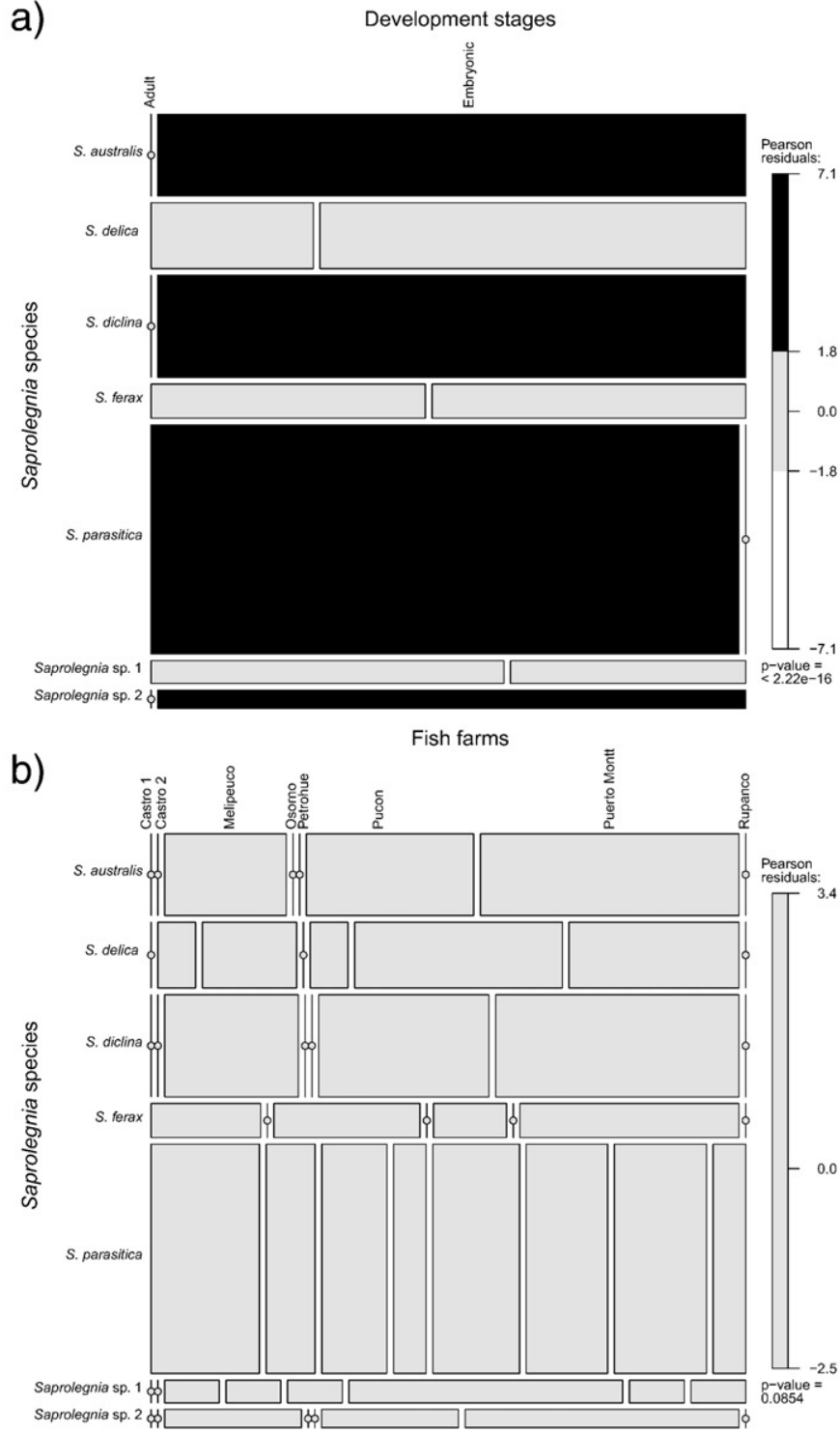

Fish species

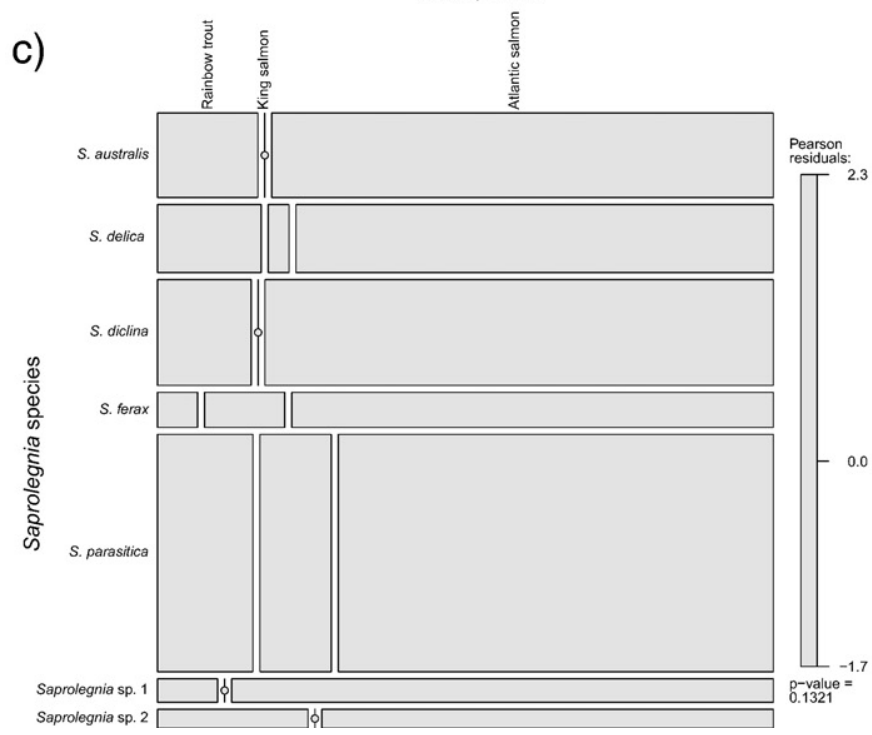

Atlantic salmon, 18 isolates for rainbow trout, and 15 isolates for king salmon) (Table 1). The Saprolegnia isolates belonged to the following species: S. parasitica (101 isolates), S. delica (8 isolates), S. ferax (7 isolates), and Saprolegnia sp. 1 (6 isolates) (Table 1).

From the samples of embryonic stages, a total of 122 isolates were obtained (102 isolates for Atlantic salmon, 20 isolates for rainbow trout) (Table 1). The isolates belong to the species $S$. diclina (45 isolates), S. australis (36 isolates), S. delica (21 isolates), S. ferax (8 isolates), Saprolegnia sp. 1 (4 isolates), and Saprolegnia sp. 2 (8 isolates) (Table 1).

\subsection{Analyses of associations of Saprolegnia species}

The correspondence analyses showed two strong associations of Saprolegnia species with the salmonid development stage (Fig. 3a). The first association was between $S$. parasitica and the adult stage of the salmonid samples (Fig. 3a), and the second association was between S. australis, S. diclina and Saprolegnia sp. 2, and the embryonic stages of salmonids (Fig. 3a). Saprolegnia species such as S. delica, S. ferax and Saprolegnia sp. 1, however, did not show any association with any particular fish developmental stage (Fig. 3a). In this analysis, these two dimensions explained the $83.50 \%$ of association of Saprolegnia species with the developmental stage. The first dimension visualized $80.98 \%$ of the association that exists between Saprolegnia species and development stages, while the second dimension visualized $2.52 \%$ of these associations (Fig. 3a). Regarding the associations of Saprolegnia species with farms and salmonid species, the correspondence analysis did not show any association. In farms, the first dimension visualized $3.22 \%$ of the association, while the second dimensions visualized $0.65 \%$ (Fig. 3b). Finally, when studying the associations of Saprolegnia species with salmonid species, the first dimension visualized 5.72\% of the association and the second dimension visualized 0.67\% (Fig. 3c).

Mosaic plot analysis also revealed significant associations of some Saprolegnia species with fish developmental stages $\left(\chi^{2}=196.29\right.$, $p<0.0001$ ). Thus, S. parasitica was significantly associated with samples of the adult stage of the salmonids (Fig. 4a), while S. australis, S. diclina and Saprolegnia sp. 2 have a significant association with samples from embryonic stages of the salmonids (Fig. 4a). Finally, the species S. delica, S. ferax and Saprolegnia sp. 1 did not show significant associations with neither adult nor embryonic stages (Fig. 4a). In addition, mosaic plot analysis showed that the associations of Saprolegnia species with salmonid farms were not significantly different $\left(\chi^{2}=3.40, p=\right.$ 0.0854). Furthermore, mosaic plot analysis showed that the Saprolegnia species were not specifically associated with any fish species $\left(\chi^{2}=\right.$ 2.32, $p=0.1321$ ) (Fig. 4c).

\section{Discussion}

In spite of the increasing impact of saprolegniosis and the improved understanding of the molecular taxonomy of Saprolegnia, the specific species suspected to cause this disease in salmonids has not been studied in detail, and in particular, in the economically important salmonid aquaculture of Chile.

In this work, we have identified the main Saprolegnia species involved in saprolegniosis in a number of selected salmonid farms covering main farming regions and salmonid species of Chile. Previous studies on the etiology of saprolegniosis in similar areas of Chile had attributed the existence of this disease only to the species S. parasitica

Fig. 4. Mosaic plot analysis of Saprolegnia species with salmonid: a. development stages, b. farms, and c. species. The size of each box is proportional to the numbers of isolates obtained from each salmonid developmental stage, farm, and species. The boxes are color-coded as follows: white, when the observed proportion is significantly much lower $(p<0.01)$ than expected under the hypothesis of a homogeneous distribution; light gray, the observed proportion is lower than expected $(0.01<p<0.05)$; and black, the observed proportion is much higher than expected $(p<0.01)$. In the analysis the information regarding the values equal to zero is displayed with $\phi$. 
(Zaror et al., 2004). However, in this study, we have found by applying a molecular taxonomic approach that other Saprolegnia species are responsible for this salmonid disease, i.e., S. australis, S. delica, S. diclina, S. ferax, and two not previously described Saprolegnia species. Furthermore, we showed that the presence of a particular Saprolegnia species is independent from the farm-origin or salmonid species, and instead is related to the developmental stage of the salmonid. Thus, our analyses showed a strong association of $S$. parasitica with adult salmonids having saprolegniosis. This confirms previous studies indicating that this species is the primary pathogen in adult salmonids (Diéguez-Uribeondo et al., 1996; Fregeneda-Grandes et al., 2007; Hatai and Hoshiai, 1992a; Hussein et al., 2001; Noga, 1993; Pottinger and Day, 1999; Willoughby and Pickering, 1977). Mass mortalities and economic losses in the salmon industry due to $S$. parasitica have been extensively reported in countries such as Canada, Ireland, Japan, Scotland, Scandinavia, and the USA (Hatai and Hoshiai, 1992a,b; Hussein and Hatai, 2002; Hussein et al., 2001; Langvad, 1994; Mueller and Whisler, 1994; Smith, 1994; van West, 2006; Willoughby, 1978). Saprolegnia parasitica is capable of affecting salmonids species such as coho salmon, masu salmon (Oncorhynchus masou), sockeye salmon (Oncorhynchus nerka), chum salmon (Oncorhynchus keta), rainbow trout, brown trout (Salmo trutta), Japanese char (Salvelinus leucomaenis), and Atlantic salmon. Moreover, S. parasitica has also been reported to having attacked other fish species different from salmonids, e.g., channel catfish (Ictalurus punctatus) and pejerrey (Odontesthes bonariensis) (Bly et al., 1992; Kitancharoen et al., 1995). The biological mechanism and virulence factors responsible for this high association of $S$. parasitica with adult salmonids are just beginning to be understood (Banfield and Kamoun, 2013; Jiang et al., 2013). A potential virulence factor enabling the pathogenicity of $S$. parasitica to the adult fish stage could be due to the presence of long spines on their cysts (Beakes, 1983; Diéguez-Uribeondo et al., 2007). These have been shown to represent attachment structures unique of this species that allows adhesion of S. parasitica more firmly than that of any other Saprolegnia species (Rezinciuc, 2013).

In embryonic stages, we found that $S$. australis, S. diclina and Saprolegnia sp. 2 were strongly associated with samples isolated from eggs and alevins. S. diclina has been generally considered as the main threat for fish eggs (Fregeneda-Grandes et al., 2007; Hussein et al., 2001; Kitancharoen and Hatai, 1996; Kitancharoen et al., 1997; Thoen et al., 2011; van den Berg et al., 2013). Regarding S. australis, this species has been considered an opportunistic pathogen (Fregeneda-Grandes et al., 2007; Hussein et al., 2001), and has been isolated from eggs of chum salmon and brown trout with symptoms of saprolegniosis. However, in a recent study, this species was shown to be pathogenic to both eggs and alevins by checking Koch postulates (Rezinciuc et al., 2014). Similar studies aiming to assess the role of $S$. australis and also S. diclina as primary pathogens in amphibian eggs have demonstrated that both species can colonize and kill embryonic stages of amphibians (Fernández-Benéitez et al., 2011; Perotti et al., 2013). Additionally, we found another species associated with the fish embryonic stages, i.e. Saprolegnia sp. 2. Some sequences from GenBank that correspond to this undescribed species have been isolated from embryonic stages of amphibians (Ault et al., 2012; Ruthig, 2009; Ruthig and Provost-Javier, 2012). However, this study constitutes the first report of the association of this undescribed species with fish embryonic stages. The biological and ecological mechanisms allowing these species to be more easily associated with this stage are unknown, but this study contributes to the identification of a set of species that should have advantageous properties to colonized embryonic stages not only in fish, but also in other organisms.

The scarce knowledge and few investigations on the Saprolegnia species involved in saprolegniosis on embryonic stages could be the result from the difficulties in identifying species. The species $S$. australis, S. diclina, and S. delica are morphologically very similar (Beakes et al., 1994; Diéguez-Uribeondo et al., 1994; Hughes, 1994). The identification of MOTUs for Saprolegnia (Sandoval-Sierra et al., 2014) now allows for an efficient identification of Saprolegnia species, especially of those with suspected diseases in the embryonic developmental stage (Liu et al., 2014; Rezinciuc et al., 2014).

Regarding, S. ferax, although this species has been considered an important pathogen in fish and amphibian embryonic stages (Cao et al., 2012; Fernández-Benéitez et al., 2008, 2011; Sarowar et al., 2014), the current analyses show that this species is not associated with saprolegniosis of embryonic stages in the Chilean farm studied. Moreover, other species such as S. delica, S. ferax and Saprolegnia sp. 1, were also isolated from both adult fish and embryonic stages, but, none of the analyses showed any association with any specific developmental stage of the fish, which suggests that these Saprolegnia species are present as secondary colonizers after the primary infection caused by S. parasitica.

The analyzed data presented here contributes to the first molecular analysis of species involved in saprolegniosis of salmonids from Chile. The identification of the species involved at different developmental stages can help us to focus on a set of pathogenic species. This will allow us to better understand the biological mechanism and ecological aspects driving these species to become pathogenic, and eventually to develop strategies in order to prevent and control this economically important disease.

Supplementary data to this article can be found online at http://dx. doi.org/10.1016/j.aquaculture.2014.09.005.

\section{Acknowledgments}

This work was supported by grants from Ministerio de Economía y Competitividad of Spain (CGL2012-39357) and Fundación San Ignacio del Huinay, Endesa, Chile (2011HUIN04). Jose V. Sandoval-Sierra was supported by grant from the European Union ITN-SAPRO-238550.

\section{References}

Arndt, R.E., Wagner, E.J., Routledge, M.D., 2001. Reducing or withholding hydrogen peroxide treatment during a critical stage of rainbow trout development: effects on eyed eggs, hatch, deformities, and fungal control. N. Am. J. Aquac. 63, 161-166.

Asche, F., Hansen, H., Tveteras, R., Tveterăs, S., 2009. The salmon disease crisis in Chile. Mar. Resour. Econ. 24, 405-411.

Ault, K.K., Johnson, J.E., Pinkart, H.C., Wagner, R.S., 2012. Genetic comparison of water molds from embryos of amphibians Rana cascadae, Bufo boreas and Pseudacris regilla. Dis. Aquat. Org. 99, 127-137.

Bailey, T.A., 1984. Effects of twenty-five compounds on four species of aquatic fungi (Saprolegniales) pathogenic to fish. Aquaculture 38, 97-104.

Banfield, M.J., Kamoun, S., 2013. Hooked and cooked: a fish killer genome exposed. PLoS Genet. 9, e1003590.

Beakes, G.W., 1983. A comparative account of cyst coat ontogeny in saprophytic and fishlesion (pathogenic) isolates of the Saprolegnia diclina-parasitica complex. Can. J. Bot. 61, 603-625.

Beakes, G.W., Wood, S.E., Burr, A.W., 1994. Features which characterize Saprolegnia isolates from salmon fish lesions - a review. In: Mueller, G.J. (Ed.), Salmon SaprolegniasisReport to Bonneville Power Administration. Environment, Fish and Wildlife Division, Portland, Oregon, pp. 33-66.

Beh, E.J., 2004. Simple correspondence analysis: a bibliographic review. Int. Stat. Rev. 72 257-284.

Bly, J.E., Lawson, L.A., Dale, D.J., Szalai, A.J., Durborow, R.M., Clem, L.W., 1992. Winter saprolegniosis in channel catfish. Dis. Aquat. Org. 13, 155-164.

Bostock, J., McAndrew, B., Richards, R., Jauncey, K., Telfer, T., Lorenzen, K., Little, D., Ross, L. Handisyde, N., Gatward, I., Corner, R., 2010. Aquaculture: global status and trends. Philos. Trans. R. Soc. B Biol. Sci. 365, 2897-2912.

Bravo, S., Midtlyng, P.J., 2007. The use of fish vaccines in the Chilean salmon industry 1999-2003. Aquaculture 270, 36-42.

Bruno, D.W., van West, P., Beakes, G.W., 2011. Saprolegnia and other oomycetes. In: Woo, P.T.K., Bruno, D.W. (Eds.), Fish Diseases and DisordersViral, Bacterial and Fungal Infections vol. 3. CABI International, Wallingford, England, pp. 669-720.

Cao, H., Zheng, W., Xu, J., Ou, R., He, S., Yang, X., 2012. Identification of an isolate of Saprolegnia ferax as the causal agent of saprolegniosis of Yellow catfish (Pelteobagrus fulvidraco) eggs. Vet. Res. Commun. 36, 239-244.

Cárdenas, C., Carmona, M., Gallardo, A., Labra, A., Marshall, S.H., 2014. Coexistence in field samples of two variants of the infectious salmon anemia virus: a putative shift to pathogenicity. PLoS ONE 9, e87832.

Cerenius, L., Fuller, M.S., Söderhäll, K., 1987. Aphanomyces astaci and Aphanomyces spp. In: Fuller, M.S., Jaworski, A. (Eds.), Zoosporic Fungi in Teaching and Research. South Eastern Publishing Corp., Athens, GA, USA, pp. 64-65. 
Coker, W.C., 1923. The Saprolegniaceae With Notes on Other Water Molds. University of North Caroline Press, Chapel Hill, North Carolina.

Costello, M.J., 2006. Ecology of sea lice parasitic on farmed and wild fish. Trends Parasitol. 22, 475-483.

Darriba, D., Taboada, G.L., Doallo, R., Posada, D., 2012. jModelTest 2: more models, new heuristics and parallel computing. Nat. Methods 9, 772-772.

Diéguez-Uribeondo, J., Cerenius, L., Söderhäll, K., 1994. Repeated zoospore emergence in Saprolegnia parasitica. Mycol. Res. 98, 810-815.

Diéguez-Uribeondo, J., Cerenius, L., Söderhäll, K., 1996. Physiological characterization of Saprolegnia parasitica isolates from brown trout. Aquaculture 140, 247-257.

Diéguez-Uribeondo, J., Fregeneda-Grandes, J.M., Cerenius, L., Pérez-Iniesta, E., AllerGancedo, J.M., Tellería, M.T., Söderhäll, K., Martín, M.P., 2007. Re-evaluation of the enigmatic species complex Saprolegnia diclina-Saprolegnia parasitica based on morphological, physiological and molecular data. Fungal Genet. Biol. 44, 585-601.

FAO, 2011. FishSta-Fishery Statistical Collections: Aquaculture Production. FAO (Food and Agriculture Organization of the United Nations), Rome (http://www.fao.org/ fishery/statistics/en (accessed 15 January 2014)).

Fernández-Benéitez, M.J., Ortiz-Santaliestra, M.E., Lizana, M., Diéguez-Uribeondo, J., 2008. Saprolegnia diclina: another species responsible for the emergent disease 'Saprolegnia infections' in amphibians. FEMS Microbiol. Lett. 279, 23-29.

Fernández-Benéitez, M., Ortiz-Santaliestra, M., Lizana, M., Diéguez-Uribeondo, J., 2011. Differences in susceptibility to Saprolegnia infections among embryonic stages of two anuran species. Oecologia 165, 819-826.

Fregeneda-Grandes, J.M., Fernández-Díez, M., Aller-Gancedo, J.M., 2001. Experimental pathogenicity in rainbow trout, Oncorhynchus mykiss (Walbaum), of two distinct morphotypes of long-spined Saprolegnia isolates obtained from wild brown trout, Salmo trutta L., and river water. J. Fish Dis. 24, 351-359.

Fregeneda-Grandes, J.M., Rodríguez-Cadenas, F., Aller-Gancedo, J.M., 2007. Fungi isolated from cultured eggs, alevins and broodfish of brown trout in a hatchery affected by saprolegniosis. J. Fish Biol. 71, 510-518

Friendly, M., 1994. Mosaic displays for multi-way contingency tables. J. Am. Stat. Assoc. 89, 190-200.

Gaikowski, M.P., Rach, J.J., Olson, J.J., Ramsay, R.T., Wolgamood, M., 1998. Toxicity of hydrogen peroxide treatments to rainbow trout eggs. J. Aquat. Anim. Health 10, 241-251.

Ghiasi, M., Khosravi, A.R., Soltani, M., Binaii, M., Shokri, H., Tootian, Z., Rostamibashman, M., Ebrahimzademousavi, H., 2010. Characterization of Saprolegnia isolates from Persian sturgeon (Acipencer persicus) eggs based on physiological and molecular data. J. Med. Mycol. 20, 1-7.

Gieseker, C.M., Serfling, S.G., Reimschuessel, R., 2006. Formalin treatment to reduce mortality associated with Saprolegnia parasitica in rainbow trout, Oncorhynchus mykiss. Aquaculture 253, 120-129.

Greenacre, M., 2007. Correspondence Analysis in Practice, Second Edition. Taylor \& Francis

Hatai, K., Hoshiai, G., 1992a. Mass mortality in cultured coho salmon (Oncorhynchus kisutch) due to Saprolegnia parasitica coker. J. Wildl. Dis. 28, 532-536.

Hatai, K., Hoshiai, G., 1992b. Saprolegniasis in cultured coho salmon (Oncorhynchus kisutch). Fish Pathol. 27, 233-234.

Hughes, G.C., 1994. Saprolegniasis, then and now: a retrospective. In: Mueller, G.J. (Ed.) Salmon SaprolegniasisReport to Bonneville Power Administration. Environment, Fish and Wildlife Division, Portland, Oregon, pp. 3-32.

Hussein, M.M.A., Hatai, K., 2002. Pathogenicity of Saprolegnia species associated with outbreaks of salmonid saprolegniosis in Japan. Fish. Sci. 68, 1067-1072.

Hussein, M.M.A., Hatai, K., Nomura, T., 2001. Saprolegniosis in salmonids and their eggs in Japan. J. Wildl. Dis. 37, 204-207.

Ibieta, P., Tapia, V., Venegas, C., Hausdorf, M., Takle, H., 2011. Chilean salmon farming on the horizon of sustainability: review of the development of a highly intensive production, the ISA crisis and implemented actions to reconstruct a more sustainable aquaculture industry. In: Sladonja, B. (Ed.), Aquaculture and the Environment - A Shared Destiny. InTech, pp. 215-246.

Igboeli, O.O., Burka, J.F., Fast, M.D., 2014. Lepeophtheirus salmonis: a persisting challenge for salmon aquaculture. Anim. Front. 4, 22-32.

Jiang, R.H.Y., de Bruijn, I., Haas, B.J., Belmonte, R., Löbach, L., Christie, J., van den Ackerveken, G., Bottin, A., Bulone, V., Díaz-Moreno, S.M., Dumas, B., Fan, L., Gaulin, E., Govers, F., Grenville-Briggs, L.J., Horner, N.R., Levin, J.Z., Mammella, M., Meijer, H. J.G., Morris, P., Nusbaum, C., Oome, S., Phillips, A.J., van Rooyen, D., Rzeszutek, E. Saraiva, M., Secombes, C.J., Seidl, M.F., Snel, B., Stassen, J.H.M., Sykes, S., Tripathy, S., van den Berg, H., Vega-Arreguin, J.C., Wawra, S., Young, S.K., Zeng, Q., DiéguezUribeondo, J., Russ, C., Tyler, B.M., van West, P., 2013. Distinctive expansion of potential virulence genes in the genome of the oomycete fish pathogen Saprolegnia parasitica. PLoS Genet. 9, e1003272.

Katoh, K., Standley, D.M., 2013. MAFFT multiple sequence alignment software version 7: improvements in performance and usability. Mol. Biol. Evol. 30, 772-780.

Kearse, M., Moir, R., Wilson, A., Stones-Havas, S., Cheung, M., Sturrock, S., Buxton, S. Cooper, A., Markowitz, S., Duran, C., Thierer, T., Ashton, B., Meintjes, P., Drummond, A., 2012. Geneious Basic: an integrated and extendable desktop software platform for the organization and analysis of sequence data. Bioinformatics 28, 1647-1649.

Kitancharoen, N., Hatai, K., 1996. Experimental infection of Saprolegnia spp. in rainbow trout eggs. Fish Pathol. 31, 49-50.

Kitancharoen, N., Yuasa, K., Hatai, K., 1995. Morphological aspects of Saprolegnia diclina Type 1 isolated from pejerrey, Odonthetes bonariensis. Mycoscience 36, 365-368.

Kitancharoen, N., Hatai, K., Yamamoto, A., 1997. Aquatic fungi developing on eggs of salmonids. J. Aquat. Anim. Health 9, 314-316.

Langvad, F., 1994. Saprolegnia in Norwegian fish farming. In: Mueller, G.J. (Ed.), Salmon SaprolegniasisReport to Bonneville Power Administration. Environment, Fish and Wildlife Division, Portland, Oregon, pp. 189-202.

Liu, Y., de Bruijn, I., Jack, A.L.H., Drynan, K., van den Berg, A.H., Thoen, E., Sandoval-Sierra, V., Skaar, I., van West, P., Diéguez-Uribeondo, J., van der Voort, M., Mendes, R.,
Mazzola, M., Raaijmakers, J.M., 2014. Deciphering microbial landscapes of fish eggs to mitigate emerging diseases. ISME J. http://dx.doi.org/10.1038/ismej.2014.44

Meyer, F.P., 1991. Aquaculture disease and health management. J. Anim. Sci. 69, 4201-4208.

Meyer, D., Zeileis, A., Hornik, K., 2006. The strucplot framework: visualizing multi-way contingency tables with vcd. J. Stat. Softw. 17, 1-48.

Moran, D., Fofana, A., 2007. An economic evaluation of the control of three notifiable fish diseases in the United Kingdom. Prev. Vet. Med. 80, 193-208.

Mueller, G.J., Whisler, H.C., 1994. Fungal parasites of salmon from the Columbia River Watershed. In: Mueller, G.J. (Ed.), Salmon SaprolegniasisReport to Bonneville Power Administration. Environment, Fish and Wildlife Division, Portland, Oregon, pp. 163-188.

Murray, A.G., Peeler, E.J., 2005. A framework for understanding the potential for emerging diseases in aquaculture. Prev. Vet. Med. 67, 223-235.

Nenadić, O., Greenacre, M., 2007. Correspondence analysis in R, with two- and threedimensional graphics: the ca package. J. Stat. Softw. 20, 1-13.

Noga, E.J., 1993. Water mold infections of freshwater fish: recent advances. Annu. Rev. Fish Dis. 3, 291-304.

Perotti, M.G., Basanta, M.D., Steciow, M.M., Sandoval-Sierra, J.V., Diéguez-Uribeondo, J., 2013. Early breeding protects anuran eggs from Saprolegnia infection. Austral Ecol. 38, 672-679.

Phillips, A.J., Anderson, V.L., Robertson, E.J., Secombes, C.J., van West, P., 2008. New insights into animal pathogenic oomycetes. Trends Microbiol. 16, 13-19.

Pottinger, T.G., Day, J.G., 1999. A Saprolegnia parasitica challenge system for rainbow trout: assessment of Pyceze as an anti-fungal agent for both fish and ova. Dis. Aquat. Org. 36, 129-141.

R Development Core Team, 2010. R: A Language and Environment for Statistical Computing. R Foundation for Statistical Computing, Vienna, Austria.

Rach, J.J., Redman, S., Bast, D., Gaikowski, M.P., 2005. Efficacy of hydrogen peroxide versus formalin treatments to control mortality associated with saprolegniasis on lake trout eggs. N. Am. J. Aquac. 67, 148-154.

Rezinciuc, S., 2013. The Saprolegniales Morpho-molecular Puzzle: An Insight Into Markers Identifying Specific and Subspecific Levels in Main Parasites. Department of Mycology, Universidad Internacional Menéndez Pelayo, Madrid.

Rezinciuc, S., Sandoval-Sierra, J.V., Diéguez-Uribeondo, J., 2014. Molecular identification of a bronopol tolerant strain of Saprolegnia australis causing egg and fry mortality in farmed brown trout, Salmo trutta. Fungal Biol. 118, 591-600.

Robertson, E.J., Anderson, V.L., Phillips, A.J., Secombes, C.J., Diéguez-Uribeondo, J., van West, P., 2009. Saprolegnia-fish interactions. In: Lamour, K., Kamoun, S. (Eds.), Oomycete Genetics and Genomics: Diversity, Interactions and Research Tools. John Wiley \& Sons, Inc., New Jersey, pp. 407-424.

Ronquist, F., Teslenko, M., van der Mark, P., Ayres, D.L., Darling, A., Höhna, S., Larget, B., Liu, L., Suchard, M.A., Huelsenbeck, J.P., 2012. MrBayes 3.2: efficient Bayesian phylogenetic inference and model choice across a large model space. Syst. Biol. 61, 539-542.

Ruthig, G., 2009. Water molds of the genera Saprolegnia and Leptolegnia are pathogenic to the North American frogs Rana catesbeiana and Pseudacris crucifer, respectively. Dis. Aquat. Org. 84, 173-178.

Ruthig, G.R., Provost-Javier, K.N., 2012. Multihost saprobes are facultative pathogens of bullfrog Lithobates catesbeianus eggs. Dis. Aquat. Org. 101, 13-21.

Sandoval-Sierra, J.V., Martín, M.P., Diéguez-Uribeondo, J., 2014. Species identification in the genus Saprolegnia (Oomycetes): defining DNA-based molecular operational taxonomic units. Fungal Biol. 118, 559-578.

Sarowar, M.N., van den Berg, A.H., McLaggan, D., Young, M.R., van West, P., 2014. Saprolegnia strains isolated from river insects and amphipods are broad spectrum pathogens. Fungal Biol. 118, 579-590.

Silvestro, D., Michalak, I., 2012. raxmlGUI: a graphical front-end for RAxML. Org. Divers. Evol. 12, 335-337.

Smith, P.R., 1994. Saprolegnia in Ireland. In: Mueller, G.J. (Ed.), Salmon SaprolegniasisReport to Bonneville Power Administration. Environment, Fish and Wildlife Division, Portland, Oregon, pp. 203-206.

Songe, M.M., Thoen, E., Evensen, Ø., Skaar, I., 2014. In vitro passages impact on virulence of Saprolegnia parasitica to Atlantic salmon, Salmo salar L. parr. J. Fish Dis. 37, 825-834.

Srivastava, S., Sinha, R., Roy, D., 2004. Toxicological effects of malachite green. Aquat. Toxicol. 66, 319-329.

Stamatakis, A., 2006. RAxML-VI-HPC: maximum likelihood-based phylogenetic analyses with thousands of taxa and mixed models. Bioinformatics 22, 2688-2690.

Thoen, E., Evensen, O., Skaar, I., 2011. Pathogenicity of Saprolegnia spp. to Atlantic salmon, Salmo salar L., eggs. J. Fish Dis. 34, 601-608.

Tiffney, W.N., 1939. The host range of Saprolegnia parasitica. Mycologia 31, 310-321.

van den Berg, A.H., McLaggan, D., Diéguez-Uribeondo, J., van West, P., 2013. The impact of the water moulds Saprolegnia diclina and Saprolegnia parasitica on natural ecosystems and the aquaculture industry. Fungal Biol. Rev. 27, 33-42.

van West, P., 2006. Saprolegnia parasitica, an oomycete pathogen with a fishy appetite: new challenges for an old problem. Mycologist 20, 99-104.

Vega-Ramírez, M., Moreno-Lafont, M., Valenzuela, R., Cervantes-Olivares, R., Aller-Gancedo, J., Fregeneda-Grandes, J., Damas-Aguilar, J., Garcl̀a-Flores, V., López-Santiago, R., 2013. New records of Saprolegniaceae isolated from rainbow trout, from their eggs, and water in a fish farm from the state of México. Rev. Mex. Biodivers. 84, 637-649.

White, T.J., Bruns, T., Lee, S., Taylor, J.W., 1990. Amplification and direct sequencing of fungal ribosomal RNA genes for phylogenetics. In: Innis, M.A., Gelfand, D.H. Sninsky, J.J., White, T.J. (Eds.), PCR Protocols: A Guide to Methods and Applications. Academic Press Inc., San Diego, CA, pp. 315-322.

Willoughby, L.G., 1978. Saprolegnias of salmonid fish in Windermere: a critical analysis. J. Fish Dis. 1, 51-67.

Willoughby, L.G., Pickering, A.D., 1977. Viable saprolegniaceae spores on the epidermis of the salmonid fish Salmo trutta and Salvelinus alpinus. Trans. Br. Mycol. Soc. 68, 91-95.

Zaror, L., Collado, L., Bohle, H., Landskron, E., Montaña, J., Avendaño, F., 2004. Saprolegnia parasitica en salmones y truchas del sur de Chile. Arch. Med. Vet. 36, 71-78. 